\title{
OPINI MASYARAKAT MUALLAF KAMPUNG SAWAH TERHADAP DA'WAH YAYASAN AL ISLAM
}

\author{
MADENI \\ Madeni@gmail.com \\ Sekolah Tinggi Ilmu Da’wah Mohammad Natsir, Indonesia
}

\begin{abstract}
ABSTRAK
Tujuan penelitian: Tujuan penelitian ini adalah untuk mengungkap opini masyarakat muallaf Kampung Sawah terhadap da'wah Yayasan Al Islam. Metode penelitian: Kualitatif. Hasil penelitian : Pertama, masyarakat Kampung Sawah Kelurahan Jati Melati Pondok Melati Bekasi Jawa Barat sebagian besar memberikan opini yang positif terhadap da'wah Yayasan Al Islam baik itu kegiatan da'wah yang dilakukan oleh Yayasan Al Islam. Kedua, sebagian besar masyarakat memberikan tanggapan yang positif terhadap keberadaan yayasan $\mathrm{Al}$ Islam yaitu memberikan tanggapan bahwa keberadaan Yayasan Al Islam memberikan Manfaat. begitu juga dengan keberadaan Yayasan Al Islam sebagian besar masyarakat kenal dengan keberadaan Yayasan Al Islam. walaupun demikian sebagian besar mmasyarakat Kampung Sawah Kelurahan Jati Melati Pondok Melati Bekasi Jawa Barat tidak pernah mengikuti kegiatan da'wah yang dilakukan oleh Yayasan Al Islam. Ketiga, dari hasil penelitian dapat disimpulkan sebagian besar nara sumber mengatakan dengan adanya Yayasan Al Islam masjid atau mushalla mengalami perkembangan dan ada juga dari para nara sumber mengatakan bahwa masing-masing masjid atau mushalla mengembangkan dirinya sendiri. Keempat, dari hasil penelitian ini dapat disimpulkan kegiatan-kegiatan yang di lakukan atau yang dijalankan oleh Yayasan Al Islam secara garis besar meliputi bidang pendidikan, bidang keagamaan, bidang sosial, dan bidang kemanusiaan.
\end{abstract}

Kata kunci : opini, muallaf, da'wah

\section{PENDAHULUAN}

Da'wah adalah amal yang paling baik setelah iman kepada Allah, karena buah dari da'wah adalah menjadikan manusia mendapat hidayah, serta menimbulkan kencintaan mereka kepada kebaikan, menjauhkan mereka dari pada 
kebatilan dan mengeluarkan mereka dari alam kegelapan menuju alam yang penuh dengan cahaya. ${ }^{1}$

Lalu apa yang akan dikatakan oleh orang-orang yang terlibat dalam da'wah, mengenai peran da'i dan pengaruhnya yang tak lain merupakan faktor yang memiliki keistimewaan tertentu dalam gerakan da'wah. ${ }^{2}$

Gerakan da'wah harus jujur untuk melakukan evaluasi dan introspeksi diri, sadar akan kelemahan dan kekuatan yang dimiliki. Allah telah merumuskan cara untuk menda'wahkan risalah Islam dalam rumusan yang singkat, jelas dan padat.

Pembinaan da'wah baik dalam hati manusia ataupun tubuh masyarakat, tidaklah berlaku sekaligus, tetapi berjalan tahap demi tahap. Menurut Muhammad Ghazali pembinaan da'wah berlaku dalam tiga tahap, tahap yang pertama penyadaran pikiran, tahap yang kedua penumbuhan keyakinan dan yang terakhir pembangunan peraturan atau organisasi. ${ }^{3}$

Adanya organisasi yang kuat dan teratur sangat dibutuhkan dalam da'wah Islamiyah, karena tanpa organisasi yang demikian ia tidak akan berdaya. Adanya organisasi da'wah yang kuat juga tidak akan bermanfaat tanpa adanya juru-juru da'wah yang terdidik dan terlatih baik seperti yang dikehendaki oleh da'wah Islamiyah itu sendiri yang bertitik tolak dari tugas pertama dan utamanya yang mengharuskan pembasmian buta huruf dan buta ilmu. ${ }^{4}$

Kerja-kerja besar sebagai tantangan utama gerakan da'wah adalah mengaplikasikan nilai-nilai Islam sebagai rahmatan lil âlamîn dalam prilaku, pola pikir, kreativitas dan program-program nyata yang bertujuan untuk mengangkat martabat manusia ditengah-tengah realitas sosial, pradaban dengan mempersiapkan du'at yang professional disertai dukungan ilmu pengetahuan dan teknologi. ${ }^{5}$

Yayasan Al Islam merupakan yayasan yang bergerak dalam bidang da'wah pada awal berdirinya yayasan ini, mendapatkan berbagai macam respon dari masyarakat bahkan ada yang menyebut bahwa yayasan ini adalah yayasan wahabi namun dengan semakin berjalannya waktu maka yayasan ini sedikit bisa membendung gerakan kristenisasi yang ada dikampung Sawah, karena daerah kampung Sawah merupakan daerah kristenisasi. Dengan keadaan ini sedikit tidak

\footnotetext{
${ }^{1}$ Musthafa Malaikah, Manhaj Dakwah,Yusuf Al-Qaradhawi, Jakarta: Al Kautsar, 2001,Cet, I, hal. 1

${ }^{2}$ Ibid., hal. 2

${ }^{3}$ Ahmad Hajmy, Dustur Dakwah Menurut Al-Qur'an, Jakarta: PT Karya Unipress, Cet. III,1994, hal. 276-277

${ }^{4}$ Ibid., hal.358-359

${ }^{5}$ Ulil Amri Syafri, Dakwah Mencermati Peluang dan Problematikanya, Jakarta:

STID Mohammad Natsir Press, Cet. I, 2007, hal. 12-13
} 
orang-orang Kristen mulai mengalami menyempitan wilayah kristenisasi, dengan keberadaan yayasan ini ada orang yang tadinya masuk Kristen kemudian bisa kembali ke Islam lagi.

Berdirinya Yayasan Al Islam diawali dengan kegiatan pengelolaan da'wah melalui dunia maya, yaitu di situs www.Al Islam.or.id yang online kali pertama pada 12 Desember 1998. Kemudian, pada tahun 2005 Yayasan Al Islam membangun sebuah Islamic Center di daerah Jati Melati, Pondok Melati, Bekasi. Tujuannya adalah untuk membangun kader-kader da'wah yang memiliki aqidah yang lurus dan pemahaman agama yang memadai. Kader-kader da'wah itu digembleng dalam sebuah kegiatan, yaitu Pesantren Tinggi Al-Islam (Ma'had Ali Al-Islam). Kegiatan inilah yang sekarang kemudian menjadi kegiatan utama Yayasan Al Islam.

Yayasan Al Islam didirikan dengan tujuan sebagai berikut.

1. Membangun, meningkatkan, dan memajukan da'wah Islam.

2. Menjadi salah satu alternatif sarana pendidikan dan pelatihan Islam.

3. Membangun sebuah portal Islam yang menjadi pusat kajian Islam yang memiliki informasi keislaman yang lengkap dan benar.

4. Menjalin persatuan dan kesatuan umat Islam yang masih mengikuti petunjuk Al-Qur'an dan As-Sunnah dengan aqidah Ahli Sunnah wal Jama'ah yang bermanhaj salafush shaleh.

5. Mengembangkan dan memberdayakan potensi sumber daya umat Islam. ${ }^{6}$

Untuk mengetahui suksesnya kegiatan yang dilakukan oleh seseorang maka tentu harus adanya evaluasi begitu juga dengan kegiatan da'wah yang kita lakukan untuk mengetahui apakah da'wah yang kita lakukan mengelami kemajuan atau kemunduran maka kita harus tahu tentang respon masyarakat terhadap da'wah yang kita lakukan apakah masyarakat meresponnya dengan respon yang baik atau sebaliknya. Oleh karena itulah dengan kita mengetahui respon masyarakat maka kita telah mendapatkan masukan bahwa da'wah yang kita lakukan selama ini belum begitu maksimal misalnya dengan itu kita bisa memperbaiki kegiatan-kegiatan da'wah agar lebih sukses dan diterima oleh masyarakat.

Supaya penelitian ini lebih terfokus dan agar tidak terjadinya pelebaran atau perluasan masalah, maka penulis membatasi pokok masalah pada warga masyarakat Kampung Sawah Kelurahan Jati Melati Pondok Melati Bekasi Jawa

\footnotetext{
${ }^{6}$ http://alislamu.com/content/view/3/ tanggal 4/4/2010
} 
Barat yang beragama Islam pada bulan Februari sampai dengan bulan Maret tahun 2011.

Dalam penulisan skripsi ini penulis akan meneliti pada kegiatan apa-apa saja yang dilakukan oleh yayasan Al Islam terhadap masyarakat sekitarnya serta bagaimana respon masyarakat kampung Sawah terhadap da'wah yayasan Al Islam.

Setiap penelitian pasti ada tujuan yang ingin dicapai oleh peneliti maka dalam penelitian ini peneliti mempunyai beragai macam tujuan diadakannya penelitian ini adalah untuk mengetahui opini masyarakat kampung Sawah terhadap da'wah yang dilakukan oleh Yayasan Al Islam Bekasi.

Pada penelitian ini penulis menggunakan metode penelitian kualitatif yaitu metode penelitian yang digunakan untuk meneliti kondisi objek yang alamiah, (sebagai lawannya adalah eksperimen) dimana peneliti menjadi instrumen kunci, tekhnik pengumpulan datanya bersifat gabungan tidak terpaku pada satu cara, analisis dan bersifat induktif atau kualitatif, dan hasil penelitiannya lebih menekan makna dari pada generalisasi. ${ }^{7}$

Pada penelitian ini penulis menggunakan metode kualitatif karena permasalahannya belum jelas, holistik, kompleks, dinamis dan penuh makna sehingga tidak memungkinkan data pada kondisi tersebut dijaring dengan menggunakan metode kuantitatif. ${ }^{8}$

Selain itu di tunjang pula oleh data-data hasil penelitian lapangan (Feald Research). Adapun teknik penulisan yang digunakan oleh penulis pada penelitian ini berpedoman pada buku "Panduan Penulisan Skripsi" yang dikeluarkan oleh STID Mohammad Natsir.

Setelah data-data di lapangan terkumpul, maka langkah selanjutnya adalah menganalisis data yang diperoleh dari lapangan adapun metode yang digunakan dalam menganalisis data tersebut adalah metode Deskrikrif Analisis yaitu analisis yang mengukur secara cermat fenomena-fenomena sosial tertentu, dimana peneliti akan mengembangkan konsep dan menghimpun data, tetapi tidak melakukan pengujian hipotesa. ${ }^{\text {' }}$

\section{HASIL DAN DISKUSI}

Peran Yayasan Al Islam di Masyarakat Kampung Sawah Kelurahan Jati Melati

${ }^{7}$ Sugiono, Metode Penelitian Kuantitatif, Kualitatif dan R\&D, Bandung: CV. Alfabeta, 2008, Cet. IV, hal. 9

${ }^{8}$ Ibid., hal. 292

${ }^{9}$ Masri Singrimbun, Metode Penelitian Survey, Jakarta: LP3ES, 1990, hal. 3. 
Dari hasil wawancara dengan beberapa nara sumber dapat diketahui sejauh mana peran Yayasan Al Islam di Masyarakat Kampung Sawah Kelurahan Jati Melati sebagai berikut:

Direktur Pesantren Tinggi Al Islam mengatakan Yayasan Al Islam mempunyai peran yang sangat penting baik dalam bidang da'wah dalam rangka memperbaiki keilmuan masyarakat seperti mengadakan kajian setiap hari selasa dan kamis bahkan sekarang ada juga program tahfidz, tahsin dan untuk malam ahad ada pengajian umum untuk masyarakat sekitar artinya peran Yayasan Al Islam dalam masyarakat sangat kelihatan sekali.

Seorang mahasiswa Pesantren Tinggi Al Islam mengatakan bahwa Yayasan Al Islam tetap berpengaruh terutama dalam menahan dan melawan gerakan kristenisasi dan berupaya untuk menahan dan menyerang ataupun melawan gerakan-gerakan kelompok aliran sesat seperti Aliran Syi'ah dan Ahmadiah untuk daerah sekitar Al Islam.

Ketua Rt 02 Rw 03 mengatakan bahwa Yayasan Al Islam di masyarakat berperan membangun masyarakat khususnya dalam bidang da'wah, dan masayarakat juga diikut sertakan dalam kegiatan Al Islam berupa ikut mengkaji ilmu di Yayasan Al Islam dan masyarakat juga mempunyai hubungan yang baik dengan Yayasan Al Islam.

Dari hasil wawancara dengan Ustadz Jaza'ul Ihsan, imam dan pengurus mushalla sekaligus ustadz di kampung Rt 02 Rw 03 Kelurahan Jati Melati dapat diketahui bahwa Yayasan Al Islam berperan di masyarakat cukup bagus dan bisa membantu masyarakat sekitar terutama di bidang sosial, seperti setiap tahun Yayasan Al Islam menyediakan hewan kurban dan juga mengadakan sunatan massal.

Ketua Yayasan Al Islam mengatakan Alhamdulillah sebenarnya kita tahu bahwa upaya untuk merusak umat Islam itu kan secara agama dengan permurtadan, secara pemikiran dengan tren-tren watching pikri, secara ekonomi mereka dijadikan miskin sehingga menjadi alat untuk menyesatkan mereka, kemudian secara pendidikan dengan mereka dibodohkan kemudian secara sosial mereka dibuat acuh tak acuh dengan agamanya. Al Islam berperan untuk menyadarkan mereka dari hal-hal seperti itu, menyadarkan umat akan pentingnya agama, akan pentingnya mengenal kebenaran, mengenal Islam, mengenal batas batas garis Islam, hal itu yang selalu kita tanamkan kepada mereka. Kemudian peran Yayasan Al Islam yang kedua adalah mengingatkan terhadap penyimpangan-penyimpangan baik itu dari luar Islam sebagai gerakan kristenisasai, atau dari dalam umat Islam sendiri berupa aliran-aliran sesat ditambah lagi dengan kegiatan-kegiatan langsung menyentuh masyarakat seperti kegiatan sosial dan pembagian sembako, pembagian hewan kurban, kita juga mengadakan hitanan massal, mengadakan pengobatan massal gratis, dan banyak hal yang memang dirasakan membantu masyarakat, meringankan masyarakat, 
selain juga kegiatan da'wah, kegiatan pendidikan, dan kegiatan pelatihan-pelatihan dan yang memang perlu ditingkatkan adalah kegiatan silaturrahmi dan mungkin yang nampak agak kurang dan perlu ditingkatkan, ada lagi karna kesibukan saya di luar yang cukup padat dan ini membutuhkan perhatian kawan-kawan kita di $\mathrm{Al}$ Islam untuk masuk kesana dan lebih aktif atau pro aktif untuk bersama dengan masyarakat diantaranya adalah mengontrakkan rumah-ruamah itu merupakan bagian exen yang nyata untuk membina masyarakat yang tinggal di tempat itu.

Bapak Zaenudin selaku pengurus masjid Ar Rahman mengatakan bahwa peran Yayasan Al Islam di masyarakat adalah kurang berperan, masyarakat ikut kadang-kadang kalau ada acara pembagian sembako.

Ketua Karang Taruna mengatakan tidak tahu tentang peran $\mathrm{Yayasan} \mathrm{Al}$ Islam di masyarakat Kampung Sawah Kelurahan Jati Melati Pondok Melati Bekasi sejauh mana sih Yayasan Al Islam berbuat sesuatu di Kampung Sawah sampai sekarang saya belum tahu yang saya tahu dari Al Islam artinya saya lihat secara kasat mata cuman orang-orang dari luar bahkan orang Kampung Sawah belum ada yang masuk ke Al Islam, karna saya dengan Al Islam jaraknya juga berjauhan bagaimana saya memberikan komentar karna sampai saat ini artinya sekian lama berdirinya saya kurang tahu atau saya yang kurang sosialisai karna saya lihat masyarakat-masyarakat di sini jarang yang ke Al Islam rata-rata dari luar.

Dari hasil wawancara dengan pengurus NU sekaligus DKM masjid $\mathrm{Al}$ Hikmah mengatakan bahwa di sini cukup jauh juga karna menyebrangi sawah atau sekarang itu komplek gren park $\mathrm{Al}$ Islam dari sana ke sini itu belum kelihatan paling sekitar sana karna itu tadi di sebrangi oleh gren park. Ketua NU ranting Jati Melati dan Ketua IPM, koordinator PNPM Mandiri, sekaligus imam masjid Al Hikmah mengatakan tidak tahu tentang peran Yayasan Al Islam di masyarakat Kampung Sawah dikarenakan karna kurang bercampur dengan Yayasan Al Islam.

\section{Penilaian Masyarakat Tentang Keberadaan Yayasan Al Islam}

Dari hasil wawancara dengan beberapa nara sumber tentang keberadaan Yayasan Al Islam dapat diketahui dari hasil wawancara dengan ketua $\mathrm{Rw}$ mengatakan jelas sekali bahwa Yayasan Al Islam memberikan banyak manfaat misalnya Yayasan $\mathrm{Al}$ Islam memberikan santunan, ada pembagian kurban.

Pak Lurah Kelurahan Jati Melati Pondok Melati Bekasi Jawa Barat mengatakan tentu keberadaan Yayasan Al Islam ada manfaatnya kalau seandainya Yayasan Al Islam tidak memberikan manfaat mungkin sudah dikomplain sama warga masyarakat.

Seorang mahasiswa Al Islam mengatakan Yayasan Al Islam memberikan manfaat diantaranya di daerah Kampung Sawah ini salah satu contohnya 
masyarakat ketika mengadakan ibadah di Al Islam merasakan ketenangan dalam beribadah.

Direktur Pesantren Tinggi Al Islam mengatakan bahwa Al Islam memberikan manfaat kepada masyarakat misalkan manfaat secara ilmu masyarakat datang ke tempat Al Islam untuk mencari ilmu kemudian ustadzustadz dari dalam juga diundang untuk mengisi kajian sedangkan manfaat secara materi pembagian daging kurban, pembagian sembako, masyarakat banyak berjualan di samping Al Islam, menyewa artinya bahwa Yayasan Al Islam itu ramai banyak pengunjugnnya akhirnya mereka jualan di lingkungan Yayasan $\mathrm{Al}$ Islam, itu menunjukkan mereka punya keuntungan dengan adanya Al Islam baik secara ilmu maupun secara materi.

Hasil wawancara dengan Ketua Rt 02 Rw 03 dapat diketahui Kalau masyarakat sendiri memandangnya biasa saja karna sedikit perbedaan memang ada, tapi perbedaan itukan bukan buat acuan menurut saya perbedaan menurtut saya dan juga menurut masyarakat perbedaan itu membuat persatuan kita lebih kuat di sana begini masyarakat yang menilai manfaat sekali.

Ustadz Jaza'ul Ihsan, imam dan pengurus mushalla sekaligus Ustadz di kampung Rt 02 Rw 03 Kelurahan Jati Melati mengatakan bahwa penilaian masyarakat tentang keberadaan YayasanAl Islam, Yayasan Al Islam Sangat bermanfaat bagi masyarakat terutama bagi mereka yang mendalami Islami termasuk termasuk bagi diri pribadi saya.

Melalui Ketua Yayasan Al Islam dapat diketahui bahwa penilaian masyarakat tentang keberadaan Yayasan Al Islam Alhamdulillah mereka positif mayoritas positif meskipun ada pihak-pihak yang kurang senang mungkin mereka kurang mengerti missi Al Islam atau mereka merasa terganggu dengan keberadaan Al Islam atau mereka memang awalnya terpropokasi dengan pihakpihak yang menumbuhkan perpecahan di tubuh umat Islam, Nashara sendiri yang kurang suka dengan Al Islam karna mereka merasa terhambat gerakannya karna Al Islam. Jelas saya lihat mereka positif dan yang negatif itu kita tidak bantah sedikitpun tapi kita jawab dengan exen dengan perbuatan nyata karna masyarakat itu ukurannya kemanfaatan apa yang bermanfaat buat mereka pasti mereka suka.

Dari hasil wawancara dengan Bapak Zaenudin selaku pengurus masjid Ar Rahman tentang penilaian masyarakat Kampung Sawah terhadap keberadaan Yayasan Al Islam mengatakan bawa penilaian masyarakat tidak kelihatan apakah masyarakat menilai positif atau tidak.

Ketua Karang Taruna dapat diketahui tentang penilaian masyarakat Kampung Sawah terhadap keberadaan Yayasan Al Islam jelas kalau masalah da'wah saya pikir bermanfaat asalkan mengikuti aturan lingkungan, saya pikir tidak ada da'wah yang tidak bermanfaat. 
Pengurus NU sekaligus DKM masjid Al Hikmah mengatakan bahwa selama da'wah itu untuk Islam saya pikir bermanfaat cuman yang sering saya katakan sama teman-teman, daerah Kampung Sawah itu kayak gimana terkenal dengan kristenisasinya hingga akhirnya teman-teman di luar berlomba-lomba untuk da'wah supaya Kampung Sawah tidak dikenal model kristenisasinya, proses kristenisasi Kampung Sawah sudah lama dan Islam yang ada di Kampung Sawah merupakan Islam yang bersifat persaudaraan yang kuat namun setelah perekonomian masyarakat rendah banyak di antara masyarakat yang pindah ke agama lain karna tidak ada kepedulian dari kita sehingga akhirnya orang-orang Kristen itulah yang peduli, kalau sekarang Al Islam ada mudah-mudahan Islam semakin berkembang.

Ketua NU ranting Jati Melati dan Ketua IPM, koordinator PNPM Mandiri, sekaligus imam masjid Al Hikmah mengatakan bahwa kalau saya selaku muslim karna namanya juga Al Islam mungkin dia juga akidahnya Islam saya tidak tahu islalmnya bagiamana karna sekarang Islam banyak, ada Islam aliran keras, ada Islam KTP mudah-mudahan Islam, Islam yang bagus saya sangat bersyukur sebagai putra Kampung Sawah yang namanya Islam sebagaimana di kenal oleh publik Kampung Sawah ini kampung kristenisasi dan saya bersyukur sebagai putra Kampung Sawah walaupun di sini dianggap kampung Kristen orang muslim sama orang Kristen akur malah sekarang yang tidak akur itu Islam sama Islamnya tidak. Saya ama non muslim aman-aman baik-baik saja, saling menghormati, sekarangkan ada banyak majlis, majlis dzikir, majlis Rasulullah, karna apa mungkin sudah banyak orang yang tidak mau dzikir, tidak mau maulid, tidak mau tahlil akhirnya habib mendirikannya. Dulu tidak ada seperti ini sekarang banyak timbul akhirnya Islam sama Islam saling olok-mengolok yang tidak maulid mengolok yang maulid yang maulid mengolok yang tidak maulid.

\section{Pengetahuan Masyarakat Tentang Keberadaan Yayasan Al Islam}

Pak Lurah Kelurahan Jati Melati dan Ketua Rw 03 tempat Yayasan Al Islam berada mengatakan kenal dengan Yayasan Al Islam bahkan ujar ketua Rw pengurus-pengurus Yayasan Al Islam sering datang ke rumah begitu juga dengan ketua Yayasan Al Islam Ustadz Farid Ahmad Okbah hubungnanya dengan ketua Rw dekat sekali begitu juga dengan ketua DKM masjid Al Islam bapak Giono sering datang ke rumah ujar ketua Rw 03 saat diwawancari oleh penulis.

Sedangkan dari pihak Kelurahan mengatakan kalau sebatas kenal dengan Yayasan Al Islam kenal atau tahu bahwa Yayasan Al Islam itu berada di lokasi atau di wilayah Kelurahan Jati Melati tapi untuk lebih detailnya saya belum tahu persis dikarenakan saya sendiri tinggal di daerah Kelurahan Jati Melati belum begitu lama. 
Dari hasil wawancara dengan Ketua Rt 02 Rw 03 mengenai pengetahuan masyarakat tentang keberadaan Yayasan Al Islam dapat diketahui bahwa dia sudah kenal dengan Yayasan Al Islam.

Begitu juga dengan hasil wawancara dengan Ustadz Jaza'ul Ihsan, Imam dan pengurus mushalla sekaligus Ustadz di Kampung Rt 02 Rw 03 Kelurahan Jati Melati mengatakan Kita tidak termasuk di dalamnya kita hanya me mantau dari luar

Dari hasil wawancara dengan ketua Yayasan Al Islam mengatakan Sebenarnya pengetahuan masyarakat tentang Al Islam kalau lihat pelang di depan itu sudah berdiri sejak tahun 2005 sekarang tahun 2011 sudah enam tahun, enam tahun itukan paling tidak mereka selalu lewat sini lihat Islamic Center Al Islam dan kita sangat terbuka siapa pun yang shalat di masjid, emang Al Islam ini unik berbeda dengan pesantren-pesantren lainnya.

Dari hasil wawancara dengan Bapak Zaenudin selaku pengurus masjid Ar Rahman dapat diketahui bahwa dia kenal dengan keberadaan Yayasan Al Islam.

Dari hasil wawancara dengan ketua Karang Taruna mengatakan kenal belum sebatas tahu keberadaannya di sana tahu, kita belum tahu kiprahnya apa, artinya saya belum pernah tahu.

Hasil wawancara dengan pengurus $\mathrm{NU}$ sekaligus DKM masjid $\mathrm{Al}$ Hikmah dapat diketahui bahwa dia kenal dengan keberadan Yayasan Al Islam.

Begitu juga dengan hasil wawancara dengan ketua NU ranting Jati Melati dan Ketua IPM, kordinator PNPM Mandiri, sekaligus imam masjid Al Hikmah mengatakan sudah kenal dengan keberadaan Yayasan Al Islam tapi tidak ikut terlibat dalam acara Yayasan Al Islam.

\section{Keterlibatan Dan Partisipasi Serta Dukungan Warga Terhadap Kegiatan Da'wah Yayasan Al Islam}

Dari hasil wawancara dengan bapak Lurah dan ketua Rw dapat diketahui bahwa pak Lurah belum pernah mengikuti kegiatan da'wah Yayasan Al Islam berbeda halnya dengan ketua Rw mengatakan dia pernah ikut dalam acara da'wah yang dijalankan oleh Yayasan Al Islam seperti ikut dalam acara tabliq akbar yang diselenggarakan oleh Yayasan Al Islam serta pernah ikut dalam acara pelepasan santri pesantren tinggi Yayasan Al Islam.

Dari hasil wawancara dengan nara sumber yang ada di Kelurahan Jati Melati Pondok Melati Bekasi Jawa Barat dapat diketahui sejauh mana partisipasi masyarakat Kelurahan Jati Melati terhadap kegiatan da'wah Yayasan Al Islam.

Dari hasil wawancara dengan ketua Rw 03 mengatakan bahwa masyarakat sangat antusias dan mendukung kegiatan da'wah yang dijalankan oleh Yayasan Al 
Islam sedangkan dari Kelurahan sendiri tidak tahu tentang partisipasi masyarakat terhadap kegiatan da'wah Yayasan Al Islam.

Sedangkan hasil wawancara dengan Direktur Pesantren Tinggi Al Islam dapat diketahui bahwa masyarakat turut membantu dalam kegiatan-kegiatan da'wah yang dilakukan oleh Yayasan Al Islam seperti menyediakan tempat untuk tempat parkir dalam acara-acara atau kegiatan besar yang tempatnya tidak cukup untuk peserta yang datang ke acara tersebut, termasuk menjaga dan sebagainya.

Hasil wawancara dengan salah seorang mahasiswa Al Islam dapat diketahui untuk tahun 2010 ini masyarakat merespon dan adanya kedekatan dengan masyarakat bahkan ada sebuah pesantren yang selama ini bertentangan dengan Al Islam mulai menerima keberadaan Yayasan Al Islam.

Dari hasil wawancara dengan Ketua Rt 02 Rw 03 mengatkan untuk terlibat dalam kegiatan Yayasan Al Islam saya tidak pernah terlibat jadi urusan $\mathrm{Al}$ Islam jadi saya tidak pernah terlibat. Sedangkan untuk masyarakat sendiri juga kalau untuk da'wah masyarakat juga tidak terlibat jadi kalau ada pengajian masyarakat juga diikut sertakan.

Sedangkan hasil wawancara dengan Ustadz Jaza'ul Ihsan, Imam dan pengurus mushalla sekaligus Ustadz di Kampung Rt 02 Rw 03 Kelurahan Jati Melati dapat diketahui bahwa Banyak diantara mereka ikut ta'lim ada juga ta'lim rutin seprti ta'lim malam minggu.

Sedangkan hasil wawancara dengan ketua Yayasan Al Islam mengatakan Alhamduillah mereka bisa mengikuti kegiatan-kegiatan, mereka minta dari awal umpamanya kajian umum, kajian ibu-ibu kemudian TPA anak-anak, kemudian keterlibatan langsung mahasantri Al Islam langsung terjun untuk mengajari mereka di rumah-rumah mereka, di masjid-masjid mereka, bahkan mengimamai mereka itu sesuatu memang dirasakan betul bagi masyarakat.

Hasil wawancara dengan ketua Karang Taruna dapat diketahui bahwa dia belum ikut berparitsipasi dalam kegiatan Yayasan Al Islam.

Begitu juga hasil wawancara dengan pengurus NU sekaligus DKM masjid Al Hikmah mengatakan saya belum pernah terlibat karna masing-masing mengurus di tempat masing-masing jadi berbarengan karna kita juga di sini pengurus masjid di bulan ramadhan, masing-masing sibuk.

Dari hasil waancara dengan ketua NU ranting Jati Melati dan Ketua IPM, koordinator PNPM Mandiri, sekaligus imam masjid Al Hikmah dapat diketahui tidak ada, sedangkan untuk masyarakat sekitar mungkin banyak, dan Alhamdulillah saya lihat banyak kegiatan yang dilakukan sama orang-orang yang tidak mampu tapi saya sendiri tidak terlibat. Sejauh mana partisipasi dan dukungan masyarakat Kampung Sawah Kelurahan Jati Pondok Melati Bekasi terhadap kegiatan da'wah Yayasan Al Islam. 
Hasil wawancara dengan Ketua Rt 02 Rw 03 mengatakan Saya sendiri dan juga masyarakat mendukung apa yang bisa kita bantu kita bantu, apa yang tidak bisa kita bantu yaa kita tidak bantu.

Hasil wawancara dengan Ustadz Jaza'ul Ihsan, Imam dan pengurus mushalla sekaligus Ustadz di Kampung Rt 02 Rw 03 Kelurahan Jati Melati dapat diketahui partisipasi serta dukungan ikut membantu dan mendukung, Kita juga sering di bantu oleh Yayasan Al Islam seprti perbaikan jalan dan Al Islam juga waktu itu memberikan satu tanah untuk masuk ke sini luar biasa kan Al Islam ini.

Hasil wawancara dengan ketua Yayasan Al Islam dapat diketahui Partisipasi secara material itu tidak banyak tapi partisipasi yang besifat dukungan, yang bersifat kerjasama, yang bersifat saling pengertian itu cukup bagus bahkan saya pernah di datangi anak-anak muda Kampung Sawah dan saya kaget karna mereka mengaku, ustadz jalani trus kegiatan Al Islam karna kami ada di belakang ustadz itu kan laur biasa dan saya tidak mengira itu timbul dari anak-anak muda Kampung Sawah karna mereka melihat ada kemanfaatannya.

Hasil wawancara dengan Bapak Zaenudin selaku pengurus masjid Ar Rahman mengatakan Saya belum lihat kita juga cuman sekali dapat undangan buka bersama, pernah buka bersama.

Hasil wawancara dengan ketua Karang Taruna dapat diketahui kalau dukungan mendukung selama tidak menyalahi kontek yang ada saya pikir tidak masalah artinya mendukung tadi yang saya bilang sejauh mana perannya artinya dia ada di Kampung Sawah berarti dia harus mau mengikuti aturan yang ada soalnya Kampung Sawah punya tradisi yang cukup kuat dari nenek moyang, tapi kalau masalah da'wah saya pikir bagus-bagus aja.

Dan hasil wawancara dengan pengurus NU sekaligus DKM masjid Al Hikmah intinya saya pribadi, sesama muslim saya mendukung ketika itu kita berjuang demi Islam cuman yang saya harapkan, yang bergerak di Kampung Sawah siapapun dia harus mengerti orang Kampung Sawah artinya orang Kampung Sawah walaupun berbeda agama, bagimana caranya supaya tidak saling menyinggung malah rahmatan lil 'alaminnya tidak kena. Seolah-olah ini bukan muslim, non muslim kita tidak peduli, tidak perlu, ini yang kurang tepat.

Hasil wawancara dengan ketua NU ranting Jati Melati dan Ketua IPM, kordinator PNPM Mandiri, sekaligus imam masjid Al Hikmah kalau saya selaku muslim saya dukung asal benar-benar jangan Islam yang ini sekarang banyak menamakan Islam tapi bukan Islam seperti gerakan yang sekarang ngebom masjid itu bukan ajaran Islam. 


\section{Kegiatan Yang Diikuti Oleh Masyarakat Kelurahan Jati Melati Pondok Melati Bekasi Jawa Barat}

Dari hasil waancara dengan Ketua Rt 02 Rw 03 dapat diketahui bahwa kegiatan yang diikuti oleh masyarakat Kelurahan Jati Melati Pondok Melati di antara kegiatan-kegiatan Yayasan Al Islam adalah kegiatan kesehatan geratis, yang dilakuan $\mathrm{Al}$ Islam masyarakat juga ikut disertakan.

Hasil wawancara dengan Ustadz Jaza'ul Ihsan, Imam dan pengurus mushalla sekaligus Ustadz di Kampung Rt 02 Rw 03 Kelurahan Jati Melati mengatakan tadinya saya ikut dulukan ada kursus bahasa arab, saya juga ikut kursus bahasa arab dan juga kegiatan ta'lim.

Hasil wawancara dengan ketua Yayasan Al Islam mengatakan selain kajian umum malam ahad, juga kajian ibu-ibu hari selasa, kajian ibu-ibu hari ahad ke tiga dan saya langsung yang memberikan kajian kepada mereka kemudian kegiatan-kegiatan sosial, seperti apa ini pembagian sembako, hitanan massal, kemudian pengobatan gratis dan juga buka puasa bersama bahkan sahur bersama itu terasa kebersamaan luar biasa dan jumlahnya cukup banyak pernah kita shalat bersama itu dan jumlahnya mencapai 500 orang padahal itu bukan puasa itu kan luar biasa.

Hasil wawancara dengan ketua Karang Taruna dapat diketahui belum pernah sekian banyak acara Karang Taruna di Karang Taruna kan ada keagamaan dan kita lihat belum mendengar ada yang mengarang di situ karnanya sudah ada masing-masing kebetulan seksi krohaniaan itu kan orang-orang $\mathrm{NU}$, jadi dia tahu pembicara, itu hal yang biasa.

Hasil wawancara dengan pengurus NU sekaligus ketua DKM masjid $\mathrm{Al}$ Hikmah dan juga ketua NU ranting Jati Melati dan Ketua IPM, kordinator PNPM Mandiri, sekaligus imam masjid Al Hikmah dapat diketahui bahwa belum pernah mengikuti kegiatan yang diadakan oleh Yayasan Al Islam.

\section{Keikutsertaan Anggota Keluarga Dalam Acara Da'wah Yayasan Al Islam}

Dari hasil wawanacara penulis dengan ketua $\mathrm{Rw} 03$ di mana Yayasan $\mathrm{Al}$ Islam berada di ketahuai bahwa dalam mengikuti acara da'wah Yayasan Al Islam ketua Rw tidak pernah mengikut sertakan saudara, anak, atau keluarga dalam acara tersebut begitu juga dengan Bapak Lurah Kelurahan Jati Melati Pondok Melati Bekasi Jawa Barat karna memang bapak lurah sendiri tidak pernah mengikuti kegiatan acara da'wah yang dilakukan oleh Yayasan Al Islam.

Sedangkan dari hasil wawancara penulis sama salah seorang mahasiswa Al Islam dapat diketahui bahwa sebagian dari masyarakat Kelurahan Jati Melati Pondok Melati Bekasi Jawa Barat mengikutsertakan anggota keluarganya. 
Hasil wawancara dengan Ketua Rt 02 Rw 03 dapat diketahui tentang keikutsertaan anggota kelurga masyarakat Kampung Sawah Kelurahan Jati Melati Pondok Melati dapat diketahui bahwa tidak ada paksaan untuk ikut atau tidak karna biasanya di Al Islam bersifat pribadi tidak memaksa bahwa kamu harus ikut kegiatan Al Islam.

Dari hasil wawancara dengan Ustadz Jaza'ul Ihsan, Imam dan pengurus mushalla sekaligus Ustadz di Kampung Rt 02 Rw 03 Kelurahan Jati Melati dapat diketahui tentang keikut sertaan anggota keluarga masyarakat Kampung Sawah Kelurahan Jati Melati diketahui bahwa diantara anggota kelurga masyarakat ada yang mengikutsertakan anggota kelurganya dalam mengikuti kegiatan da'wah Yayasan Al Islam dengan bukti adanya anggota kelurga masyarakat Kampung Sawah yang menikah dengan salah seorang mahasiswa.

Dari hasil wawancara dengan ketua Yayasan Al Islam dapat diketahui tentang keikutsertaan anggota keluarga dalam mengikuti kegiatan da'wah Yayasan Al Islam bahwa dianatara masyarkat ada yang mengikutsertakan anggota keluarganya dalam mengikuti acara da'wah Yayasan Al Islam.

Dari hasil wawancara dengan Bapak Zaenudin selaku pengurus masjid Ar Rahman dapat diketahui tentang keikutsertaan anggota keluarganya dalam mengikuti acara kegiatan da'wah Yayasan Al Islam bahwa dia tidak mengikutsertakan angota kelurganya dalam mengikuti acara da'wah Yayasan Al Islam. Selanjtunya dia mengatakan dalam ceramahnya akur tapi dalam prakteknya dia melepaskan remaja-remaja, mengajak tiap-tiap rumah akhirnya melepaskan tradisi di sini makanya kita tidak mau berdekatan dengan Al Islam, di sini kan orang meniggal ada 3 hari, 7 hari mungkin tidak ada perintahnya tapi tradisi di sini, bagus juga ada bacaan al qur'an, dzikir, tahlil, tidak boleh tahlil, tidak boleh dzikir, tidak boleh maulid, ini kan udah jadi kebiasaan.

Dari hasil waancara dengan ketua Karang Taruna tentang keikutsertaan anggota keluarga dalam mengikuti kegiatan Yayasan Al Islam dapat diketahui bahwa selama ini anggota keluarga atau warga masyarakat hanya mengikuti kajiankajian yang ada di lingkungan ini saja karna di lingkungan ini juga ada masjid.

Hasil wawancara dengan pengurus NU sekaligus DKM masjid Al Hikmah dan wawancara dengan ketua NU ranting Jati Melati sekaligus imam masjid al hikmah mengatakan anggota keluarga belum ikut atau tidak mengikuti kegiatan yang diadakan oleh Yayasan Al Islam.

\section{Kegiatan Yang Diikuti Oleh Anggota Keluarga Masyarakat Kelurahan Jati Melati Pondok Melati Bekasi Jawa Barat}

Dari hasil wawancara dengan salah seorang mahasiswa Al Islam dapat diketahui bahwa kegiatan yang diikuti oleh anggota keluarga masyarakat 
Kelurahan Jati Melati Pondok Melati Bekasi Jawa Barat yaitu kegiatan kajian baik itu kajian malam ahad begitu juga dengan kegiatan ibu-ibu yang dijadwalkan hari selasa siang dan juga dengan kegiatan kajian hari kamis.

Dari hasil wawancara dengan Ketua Rt 02 Rw 03 dapat diketahui jenis kegiatan yang diikuti oleh anggota keluarga masyarakat kelurahan jati melati pondok melati berupa kajian Islami.

Sedangkan hasil wawancara dengan ketua Yayasan Al Islam tentang kegiatan yang diikuti oleh anggota keluarga masyarakat Kelurahan Jati Melati Pondok Melati berupa kegiatan yang sesuai dengan kebutuhan masyarakat itu sendiri karna ketika masyarakat datang ke Al Islam itu disebabkan karna memang ada kubutuhan, kalau mereka ingin mendengarkan kajian mereka datang membawa anak, isterinya ada juga kajian prempuan tidak mungkin datang bapakbapak ada juga kegiatan yang dihadiri oleh anak-anak termasuk banyak yang hadir di waktu shalat jum'at atau di waktu shalat traweh karna memang di kita bacaannya agak panjang, bacaannya bagus bacaan alqur'annya menyejukkan itu juga daya tarik masyarakat.

Hasil wawancara dengan ketua Karang Taruna Kelurahan Jati Melati Pondok Melati mengatakan bahwa tidak ada kegiatan yang diikuti oleh anggota keluarganya, begitu juga dengan hasil wawancara dengan pengurus NU sekaligus DKM masjid Al Hikmah mengatakan tidak pernah mengikutsertakan anggota keluarganya dalam mengikuti kegiatan da'wah Yayasan Al Islam.

\section{Perkembangan Masjid Atau Mushalla Setelah Datangnya Da'wah Yayasan Al Islam}

Dari hasil wawancara terhadap nara sumber dapat diketahui perkembangan masjid atau mushalla setelah datangnya da'wah Yayasan Al Islam. Dari ketua Rw mengatakan bahwa masjid atau mushallla mengalami perkembangan setelah datangnya da'wah Yayasan Al Islam bahkan dari santrisantri Yayasan Al Islam ada yang menambahkan pelajaran-pelajaran di mushalla berbeda dengan sebelum datangnya Yayasan Al Islam mememang perkembangannya sudah ada tapi dengan kedatangan Yayasan Al Islam menjadi lebih berkembang.

Dari pihak kelurahan sendiri mengatakan cukup bagus tapi pak Lurah mengatakan ketika masuk di Kelurahan Jati Melati proses pembangunan masjid atau mushalla seperti biasa saja dalam arti tidak diam namun trus berlanjut tapi hal itu kata pak Lurah tidak tahu persis apakah itu disebakan karna adanya Yayasan Al Islam atau tidak.

Dari hasil wawancara dengan Direktur Pesantren Tinggi Al Islam mengatakan dari bukti yang ada mislanya 13 tempat mahasiswa mengisi kajian 
atau ta'lim itu yang mahasiswanya belum yang ustadz-ustadz bahwa keberadaan Yayasan Al Islam banyak membanatu terutama dalam masalah-masalah ibadah dan pengaiian. Sedangkan dari mahasiswa Al Islam sendiri mengatkan atau beberapa masjid yang sudah mengikuti da'wah atau apa-apa yang diterapkan oleh Yayasan Al Islam.

Dari hasil wawancara dengan Ketua Rt 02 Rw 03 dapat diketahui tentang perkembanagn masjid atau mushalla setelah datangnya da'wah Yayasan Al Islam mengalami perkembangan yang dulunya sepi dan sekarang jama'ahnya bertambah di tambah lagi dengan kedatangan mahasiswa $\mathrm{Al}$ Islam ke masjid atau mushalla untuk shalat berjama'ah.

Hasil wawancara dengan Ustadz Jaza'ul Ihsan, Imam dan pengurus mushalla sekaligus Ustadz di Kampung Rt 02 Rw 03 Kelurahan Jati Melati tentang perkembangan masjid atau mushalla setelah datangnya da'wah yayasan $\mathrm{Al}$ Islam ada lebih berpacu dan peningkatan baik dalam bidang agamana khususnya dalam bacaan al qur'an begitu juga dengan da'wahnya.

Hasil wawancara dengan ketua Yayasan $\mathrm{Al}$ Islam dapat diketahui tentang perkembangan masjid atau mushalla setelah datangnya da'wah Yayasan Al Islam cukup aktif bahkan masyarakat meminta kepada Yayasan Al Islam untuk melibatkan para santri dalam kegiatan warga masyarakat baik dalam bentuk ceramah-ceramah, khutbah jum'at, dalam bentuk kegiatan-kegiatan ramadhan, cukup banyak dan memang trus ditingkatkan.

Dari hasil wawancara dengan Bapak Zaenudin selaku pengurus masjid Ar Rahman tentang perkembangan masjid atau mushalla setelah datangnya da'wah Yayasan Al Islam adalah berjalan tapi perkembangannya msing-masing berlomba untuk mengembangkan masjid atau mushallanya masing-masing.

Dari hasil wawancara dengan ketua Karang Taruna Kelurahan Jati Melati Pondok Melati Bekasi dapat diketahui tentang perkembangan masjid atau mushalla setelah datangnya da'wah Yayasan $\mathrm{Al}$ Islam perkembangannya biasabiasa saja. Dengan bukti berdirinya mushalla persis di samping Yayasan Al Islam kalau memang da'wah Yayasan Al Islam cukup berpengaruh maka masyarakat tidak susah payah untuk mendirikan mushalla di samping Yayasan Al Islam.

Hasil wawancara dengan pengurus NU sekaligus DKM masjid $\mathrm{Al}$ Hikmah dapat diketahui perkembangan masjid atau mushalla setelah datangnya da'wah Yayasan Al Islam masing-masing bergerak untuk mengembangkan masjid atau mushallanya masing-masing.

Dan hasil wawancara dengan ketua NU ranting Jati Melati dan Ketua IPM, koordinator PNPM Mandiri, sekaligus imam masjid Al Hikmah dapat diketahui tentang perkambangan masjid atau mushalla setelah datangnya da'wah Yayasan Al Islam sebelum datangnya da'wah Yayasan Al Islam masjid atau mushalla sudah mengalami perkembangan. 


\section{Jenis Kegiatan Yang Dilaksanakan Yayasan Al Islam Di Masjid Atau Mushalla}

Dari hasil wawancara dengan ketua Rw 03 Kelurahan Jati Melati Pondok Melati Bekasi Jawa Barat mengatakan bentuk kegiatan yang dilakukan oleh Yayasan Al Islam di masjid atau mushalla yang ada di Kelurahan Jati Melati Pondok Melati Bekasi Jawa Barat dalam bentuk mengadakan kajian atau mengajar di masjid atau mushalla, begitu juga dengan hasil wawancara dengan mahasiswa Al Islam mengatakan bentuk kegiatan yang dilakukan oleh Yayasan Al Islam di masjid atau mushalla yang ada di Kelurahan Jati Melati Pondok Melati dalam bentuk kajian atau mengisi kajian di masjid atau mushalla baik itu mengajar TPA mengajar jama'ah baik bapak-bapak atau ibu-ibu.

Dari hasil wawancara dengan Ketua Rt 02 Rw 03 dapat diketahui bahwa kegiatan yang di lakukan oleh Yayasan Al Islam di masjid atau mushalla yang ada di Kelurahan Jati Melati Pondok Melati Bekasi berupa kajian Islami dan juga kegiatan silaturrahmi sama masyarakat untuk mengetahui apa-apa yang diinginkan dan diperlukan oleh masyarakat.

Dan hasil wawancara dengan Ustadz Jaza'ul Ihsan, Imam dan pengurus mushalla sekaligus Ustadz di Kampung Rt 02 Rw 03 Kelurahan Jati Melati dapat diketahui bahwa kegiatan yang dilakukan oleh Yayasan Al Islam di masjid atau mushalla berupa menempatkan atau memberiakan kesempatan kepada santrisantrinya di mushalla atau masjid-masjid untuk mengajar secara cuma-cuma atau geratis untuk kemakmuran masjid dan mushalla.

Hasil wawancara dengan ketua Yayasan Al Islam dapat diketahui bahwa kegiatan-kegiatan yang dilakuakan oleh Yayasan $\mathrm{Al}$ Islam di masjid atau mushalla yang ada di kelurahan jati melati pondok melati berupa kajian-kajian, mengimami shalat teraweh, kemudian juga pembelajaran-pembelajaran pembinaan dan lain sebagainya.

Dari hasil wawancara dengan ketua Karang Taruna mengatakan tidak tahu, saya tidak pernah dengar, yang saya tahu ada kurban, tapi itu hal yang biasa karna semua masjid atau mushalla melakukan itu, artinya apalagi Al Islam yang begitu besar, masjid atau mushalla yang kecil pun melakuaknnya.

Dari hasil wawancara dengan pengurus NU sekaligus DKM masjid $\mathrm{Al}$ Hikmah dapat diketahui jenis kegiatan yang dilaukan Al Islam berupa PKL anakanak mahasiswa berupa ikut membantu pengajian anak-anak TPA.

\section{Penilaian Masyarakat Terhadap Kegiatan Da'wah Yayasan Al Islam}

Dari hasil wawancara penulis dengan nara sumber dapat diketahui siapasiapa saja yang merespon positif seorang mahasiswa yang penulis wawancarai 
mengatakan ada beberapa orang diantaranya salah seorang yang mempunyai perusahaan daur ulang sampah, ada juga penjual makanan dan minuman sedangkan yang merespon negatif ada sebagian masyarakat yang sebenarnya itu hanya masalah profokasi yaitu maslah maulid karna sebagian besar masyarakat sekitar mempercayai adanya maulid Nabi terutama di belakang Al Islam kemudian masyarakat yang adai di depan samping Al Islam sebagian besar diantara mereka kalau tidak Nasrani, Islam tapi Islamnya yang pemahamannya seperti pemahaman habib memang kejadian pernah bahkan tembok-tembok $\mathrm{Al}$ Islam ini dicoret-coret itu menunjukkan unsur kebencian mereka terhadap Yayasan Al Islam istilahnya tidak suka dengan Al Islam dengan cara seperti itu di dalam masalah itu tapi kita tetap berusaha untuk mendekati mereka dengan cara misalkan mengadakn kurban bersama dengan masyarakat artinya hubungan bermasyarakat dengan mereka, cuman dari informasi yang ada, memang ada sebagian masyarakat di sekitar Al Islam ini sedikit terprofokasi terutama orangorang yang condong ke Syi'ah mereka tidak faham, mereka sedikit memprofokasi sebagian masyarakat dekat dengan Al Islam, bagaimana supaya untuk mengatasi masalah mungkin kita mengadakan baksos, kegiatan, mengadakan pembagian daging kurban mereka itu berparatisipasi tapi dalam kegiatan da'wah ke ilmuan masalah Islam jarang.

Dari hasil wawancara dengan Direktur Pesantren Tinggi Al Islam mengatakan bahwa yang merspon positif dan negatif ada dimana-mana mereka menggap bahwa ajaran dari Al Islam itu berbeda dengan apa yang mereka dapatkan dari guru-guru mereka dan perbedaan ini sebenarnya hanya perbedaan dalam masalah puruq karna ketidak tahuan itulah yang menyebabkan mereka tidak respek dengan Al Islam, sedangkan menurut Lurah Jati Melati masyarakat merespon positif keberadaan Yayasan Al Islam dengan bukti kalu seandainya masyarakat meresponnya negatif maka tentu dari masyarakat ada yang komplein ke kantor Kelurahan selama inikan belum ada.

Dan dari pihak ketua Rw mengatakan yang merespon positif atau yang pro kepada Al Islam tidak bisa disebutkan karna kalau ada undangan dari Yayasan Al Islam mereka hadir kalu ada kesempatan. Sedangkan yang merespon negatif atau yang kontra dengan Yayasan $\mathrm{Al}$ Islam sebagian besar dari mereka adalah non Muslim ujar ketua Rw ketika diwawancarai oleh penulis disebabkan mungkin mereka merasa terganggu.

Dari hasil wawancara dengan Ketua Rt 02 Rw 03 tentang penilaian masyarakat terhadap kegiatan da'wah Yayasan Al Islam mengatakan da'wah khususnya pendidikan kalau da'wahnya menurut saya sih dia dikhusukan untuk santri di sana tapi dilain hari khusus untuk masarakat di sini kalau da'wah sepenuhnya saya kurang mengetahuai kalau da'wah, masyarakat juga mengenai kegiatan da'wahnya bagus. 
Hasil wawancara dengan Ustadz Jaza'ul Ihsan, Imam dan pengurus mushalla sekaligus Ustadz di Kampung Rt 02 Rw 03 Kelurahan Jati Melati selaku ustadz yang ada di Rt $02 \mathrm{Rw} 03$ Kelurahan Jati Melati tentang penilaian masyarakat terhadap kegiatan da'wah Yayasan Al Islam adalah baik-baik saja mungkin ada pro dan kontra disebabkan karna ketidak tahuan atau tidak faham sebenarnya kalau kita faham sebenarnya tidak ada yang namanya perbedaan selama tidak melenceng dari Al Qur'an dan assunnah, tapi kalau masyarakat memang ada yang pro dan kontra, ada yang ikut dan ada juga yang tidak.

Dan hasil wawancara dengan ketua Yayasan Al Islam dapat diketahi tentang penilaian masyarakat Kampung Sawah terhadap kegiatan da'wah Yayasan Al Islam adalah masyarakat sampai sekarang masih responsif dan tentunya yang harus dilakuan adalah upaya terus menerus dan sekaligus melibatkan mereka.

Dari hasil wawancara dengan ketua Karang Taruna mengatakan tidak bisa memberiakn penilaian terhadap kegiatan da'wah Yayasan Al Islam.

Begitu juga dengan hasil wawancara dengan pengurus NU sekaligus ketua DKM Masjid Al Hikmah mengatakan tidak bisa memberikan komentar tentang penilaian masyarakat terhadap kegiatan da'wah Yayasan Al Islam sama halnya juga dengan hasil wawancara dengan ketua NU ranting Jati Melati dan Ketua IPM, koordinator PNPM Mandiri, sekaligus imam masjid Al Hikmah mengatakan tidak bisa memberikan penilaian terhadap kegiatan da'wah Yayasan Al Islam.

\section{Sifat Da'wah Yayasan Al Islam}

Dari hasil wawancara dengan beberapa nara sumber dapat diketahui bahwa Sebagian besar nara sumber yang penulis wawancarai mengatakan bahwa sifat da'wah Yayasan Al Islam adalah bersifat terbuka, misalkan hasil wawancara dengan Direktur Pesantren Tinggi Al Islam dapat diketahui bahwa sifat da'wah Yayasan Al Islam bersifat terbuka sekali tidak ada yang ditutup-tutupi, begitu juga hasil wawancara dengan ketua Rw 03 Kelurahan Jati Melati Pondok Melati Bekasi Jawa Barat mengatakan bahwa sifat da'wah Yayasan Al Islam bersifat terbuka dengan bukti adanya undangan da'wah kepada Rw.

Hasil wawancara dengan pihak Kelurahan yaitu Bapak Lurah Kelurahan Jati Melati Pondok Melati Bekasi Jawa Barat tidak tahu dengan alasan dia tidak tahu benyak tentang Yayasan Al Islam dia cuma tahu bahwa Yayasan Al Islam itu berada di wilayah itu dikarnakan karna tidak adanya laporan tentang Yayasan Al Islam kepadanya. Seorang mahasiswa Al Islam sendiri yang penulis wawancara mengatakan da'wah Yayasan Al Islam itu terbuka itulah sebabnya Al Islam tidak menggunakan di depannya kata siapa yang masuk harus menggunakan jilbab artinya Yayasan ini ibersifat terbuka dan tidak tertutup. 
Hasil wawancara dengan Ketua Rt 02 Rw 03 dapat diketahui bahwa Sifat da'wah Yayasan yaa kebanyakan tertutup dikarenakan sebagian besar kegiatannya dikhusus untuk santri sedangkan terbukanya kegiatan itu khusus untuk warga di sini mislakan kegiatan pengajian bapak-bapak. Sedangkan kegiatan yang tertutupnya masalah pendidikan yang membahas hadits-hadits karna itu di lingkungannya.

Hasil wawancara dengan Ustadz Jaza'ul Ihsan, Imam dan pengurus mushalla sekaligus Ustadz di Kampung Rt 02 Rw 03 Kelurahan Jati Melati selaku Ustadz di Kampung Sawah Rt 02 Rw 03 dapat diketahui bahwa sebenarnya sifat da'wah Yayasan Al Islam adalah terbuka misalkan di bulan ramadhan pihak Yayasan Al Islam mengundang tokoh-tokoh di lingkungan Kecamatan, Kelurahan, diadakan oleh Al Islam seperti buka bersama dan sebagianya jadi terbuka dan saran kita bagaimana supaya masyarakat kenal, orang kan kalau kenal akan timbul rasa sayang sekarang bagaimana da'wah Al Islam bisa berkembng bisa maju di lingkungan mereka harusnya memperkenlkan diri bagaimana istilahnya disini bagaimana sedikit-sedikit insya'Allah akan tertarik.

Hasil wawancara dengan ketua Yayasan Al Islam dapat diketahu bahwa sifat da'wah Yayasan Al Islam adalah terbuka dan bermanfaat bagi masyarkat dan yang terpenting lagi bahwa Yayasan Al Islam adalah lembaga yang tidak panatik terhadap satu kelompok, kita ini merangkul semuanya yang penting di atas kebenaran makanya namanya Al Islam, boleh ikut selama di atas kebenaraan.

Hasil wawancara dengan Bapak Zaenudin selaku pengurus masjid Ar Rahman dapat diketahui bahwa sifat da'wah Yayasan Al Islam mungkin maunya adalah terbuka tapi kadang yang hadir hanya dari kalangan Al Islam sendiri dan jama'ah yang ada disini tidak hadir ujar bapak Zaenudin ketika di wawancara oleh penulis.

Hasil wawancara dengan ketua Karang Taruna dapat diketahui bahwa tidak tahu tentang sifat da'wah Yayasan Al Islam dan tidak berani bilang apakah tertutup dan terbuka.

Hasil wawancara dengan pengurus NU sekaligus DKM masjid Al Hikmah dapat diketahui bahwa tidak bisa memberikan gambaran tentang sifat da'wah Yayasan Al Islam dikarenakan karna tidak pernah terlibat langsung dengan Yayasan Al Islam.

\section{Kegiatan Yang Diminati dan Disukai Oleh Masyarakat Kelurahan Jati Melati Dari Kegiatan Da'wah Yayasan Al Islam .}

Dari hasil wawancara dengan beberapa nara sumber dapat diketahui kegiatan apa yang paling diminati oleh masyarakat diantara kegiatan-kegiatan 
da'wah Yayasan Al Islam. Dari pihak Rw sendiri mengatakan bahwa kegiatan yang paling diminati oleh masyarakat adalah kegiatan sosial dengan alasan karna kegiatan ini bersifat umum siapa saja bisa masuk dalam keigatan ini dan siapa saja bisa menikmati beda dengan kegiatan da'wah mungkin yang bisa orang-orang tertentu saja. Sedangkan dari pihak Kelurahan mengaku belum tahu kegiatan apa yang diminati oleh masyarakat dengan alasan belum tahu tentang kegiatankegiatan atau program-program yang dijalankan oleh Yayasan Al Islam disebabkan karna belum adanya laporan yang masuk ke Kelurahan dari pihak Yayasan, sedangkan dari Direktur Pesantren Tinggi Al Islam mengatakan bahwa kegiatan-kegiatan yang paling diminati oleh masyarakat adalah kegiatan kajian baik itu devisi wanita, pengajian umum, pengajian malam ahad begitu juga dengan program dirasat yang diperuntukkan untuk masyarakat yang tidak tinggal di dalam Yayasan Al Islam begitu juga dengan program kursus bahasa Arab sedangkan dari masyarakat sekitar kegiatan yang paling diminati adalah kegiatan pembagian sembako, karna kebanyakan masyarakat kan tidak berilmu dan biasanya masyarakat menyukai hal-hal yang berbentuk materi. Sedangkan dari mahasiswa mengatakan sudah berupaya dan berusaha untuk melaksanakan kegiatan-kegiatan sperti pesantren kilat setiap tahun untuk membina keIslam an para remaja, dari smp, sma begitu juga untuk mahasiswa yang ingin mendalami Islam.

Hasil wawancara dengan Ketua Rt 02 Rw 03 dapat diketahui bahwa kegiatan yang paling disukai oleh masyarakat adalah kegiatan pembagian sembakio, yang hampir rutin dilakukan oleh Yayasan Al Islam kegiatan itu benarbenar bisa membanatu masyarakat begitu juga dengan kegiatan pengobatan geratis bagi masyarakat. Begitu juga dengan hasil wawancara dengan ketua Yayasan Al Islam mengatakan bahwa kegiatan yang paling disukai oleh masyarakat adalah kegiatan-kegiatan yang bersifat materil diantaranya kegiatan pembagian sembako dan juga kegiatan buka bersama.

Hasil wawancara dengan ketua Karang Taruna dapat diketahui bahwa dia tidak tahu tentang kegiatan yang paling sidukai oleh masyarakat diantara kegiatan Yayasan Al Islam begitu juga dengan hasil wawancara dengan ketua NU ranting Jati Melati dan Ketua IPM, kordinator PNPM Mandiri, sekaligus imam masjid Al Hikmah dapat diketahui bahwa tidak tahu juga tentang kegiatan yang paling disukai oleh masyarakat kelurahan jati melati pondok melati bekasi.

Hasil wawancara dengan pengurus NU sekaligus DKM masjid Al Hikmah mengatakan Saya tidak mau menutup mata bahwa da'wah sekarang tidak cuman di Al Islam gitu, sekarangkan da'wah materi itulah yang pernah direbut oleh non muslim akhirnya Kampung Sawah menjadi seperti ini.

\section{KESIMPULAN}


Dari hasil penelitian penulis di lapangan tentang opini masyarakat Kampung Sawah terhadap da'wah Yayasan Al Islam yaitu wawancara langsung dengan nara sumber dapat disimpulkan:

1. Masyarakat Kampung Sawah Kelurahan Jati Melati Pondok Melati Bekasi Jawa Barat sebagian besar memberikan opini yang positif terhadap da'wah Yayasan Al Islam baik itu kegiatan da'wah yang dilakukan oleh Yayasan Al Islam.

2. Sebagian besar masyarakat memberikan tanggapan yang positif terhadap keberadaan yayasan Al Islam yaitu memberikan tanggapan bahwa keberadaan Yayasan Al Islam memberikan Manfaat. begitu juga dengan keberadaan Yayasan Al Islam sebagian besar masyarakat kenal dengan keberadaan Yayasan Al Islam. walaupun demikian sebagian besar mmasyarakat Kampung Sawah Kelurahan Jati Melati Pondok Melati Bekasi Jawa Barat tidak pernah mengikuti kegiatan da'wah yang dilakukan oleh Yayasan Al Islam.

3. Dari hasil penelitian dapat diseimpulkan sebagian besar nara sumber mengatakan dengan adanya Yayasan Al Islam masjid atau mushalla mengalami perkembangan dan ada juga dari para nara sumber mengatakan bahwa masing-masing masjid atau mushalla mengembangkan dirinya sendiri.

4. Dari hasil penelitian ini dapat disimpulkan kegiatan-kegiatan yang di lakukan atau yang dijalankan oleh Yayasan Al Islam secara garis besar meliputi bidang pendidikan, bidang keagamaan, bidang sosial, dan bidang kemanusiaan.

\section{DAFTAR PUSTAKA}

Abdullah, Muhammad Yatimin, Studi Islam Kontemporer, Jakarta: Amzah, 2006

Abu Bakar, Hasauddin, Meningkatkan Mutu Da'wah, Jakarta: Media Da'wah, 1999 
Ali, Atabik dan Ahmad Zuhdi Muihdlor, Kamus Kontemporer Arab-Indonesia, Yogyakarta: Multi Karya Grafika Pondok Pesantren Krapyak

Al-Jazairi, Abul harits Muhammad bin Ibrahim Khirraj As-Salafi, Syarbu AlMandhumah Al-Baiquniyah, terj: Abu Hudzaifah, Sanggrahan: AlGhuroba', 2006

Annisa, Abu, "Lima Tabun WWW.alislam.or.id, Jakarta: 200

Arifin, Muhammad, Psikolgi Da'wah Suatu Pengantar Studi, Jakarta: PT Bumni Aksara, 2000

Bachtiar, Wardi, Metodologi Penelitian Ilmu Da'wah, Jakarta: Logos Wacana Ilmu, 1997

Bagus, Lorens, kamus filsafat Jakarta: Pt Gramedia, 2000

Busyairi, Badruzzaman, "Rumah Ibadat di Kota Bekasi” Bekasi: Porum Kerukunan Umat Beragama (FKUB), 2009

Departemen Dalam Negeri Direktorat Jenderal Pemberdayaan Masyarakat Dan Desa.

Hajmy, Ahmad, Dustur Da'wah Menurut Al-Qur'an, Jakarta: PT Karya Unipress, 1994

Dustur Da'wah Menurut Al-Qur'an, Jakarta: Bulan Bintang, 1991

Hamka, Tafsir Al Ažhar, Singapura: Kerja Print Pte Ltd, 2007 
Ibrahim bin Muhammad, Abul harits Syarbu Al-Mandhumah Al-Baiquniyah, terj: Hassan, A. Qadir, Ilmu Mushthalah Hadits, Bandung: CV diponogoro, 1983 Irfani, "Peran Yayasan Al Islam Periode 2005-2007 Dalam Da'wah Di Kampung Sawah", Makalah, Bekasi: Perpustakaan Yayasan Al Islam

Komaruddin, Yoke Tjuparmah S. Komaruddin, Kamus Istilab Karya Ilmiah, Jakarta: Bumi Aksara, 2000

Kayo, Rb, Khatib Pahlawan, Manajemen Da'wah dari Da'wah Konvesional Menuju Da'wah Professional, Jakarta: Amzah, 2000

Lajnah 'Ilmiyyah bi Ma'had Al-Aimah wa Al-Khuthaba, Sirah Nabawiyah dan Da'wah, terj: Nabhan Idris dan Hidayatullah, Jakarta: wamy, 1998

Lubis, Basrah, Pengantar Ilmu Da'wah, Bekasi: CV. Tursina, 1992

Malaikah, Musthafa, Manhaj Da'wah,Yusuf Al-Qaradhawi, Jakarta: Al Kautsar, 2001

Moleong, Lexy J, Metodologi Penelitian Kualitatif, Bandung: PT Remaja Rosdakarya, 2004

Mulyana,Deddy, Metode Penelitian Kualitatif, Bandung: PT Remaja Rosdakarya, 2002

Mundzir, Hafidz, Mukhtasar Shahih Muslim, Quwait: Ad Darul Quwaitiah, 1969 
Nuh, Sayid Muhammad, Figh Ad-Da'wah Al-Fardiyah fi Al-Manbaji Al-Islam, terj: Ashfa Afkarina, Surakarta: Era Intermedia, 2000

Razak, Yusron (ed), Sosiologi Sebuah Pengantar Tinjauan Pemikiran Sosiologi Perspektif Islam, Jakarta: Laboratorium Sosiologi Agama, 2008

Rekpitulasi Penduduk Se-Kelurahan Jati Melati (Wni, Wni Keturunan dan Wna). Ruslan, Rosady, Manajemen Humas dan Komunikasi Konsepsi dan Aplikasi, Jakarta: Raja Grapindo Persada, 2002

Salam,Tahrudin, "Sejarah Kristen Kampung Sawab” Makalah, Bekasi: Perpustakaan Yayasan Al Islam

Singrimbun, Masri, Metode Penelitian Survey, Jakarta: LP3ES, 1990

Soemirat, Soleh dan Elvinaro Ardianto, Dasar-dasar Public Relation, Jakarta: Remaja Rosdakarya 2005

Sugiono, Metode Penelitian Pendidikan,Pendekatan kuantitatif. Kualitatif, dan R dan D, Jakarta: Alfabeta, 2008 Metode Penelitian Kuantitatif, Kualitatif dan RéD, Bandung: CV. Alfabeta, 2008

Syafri, Ulil, Amri, Da'wah Mencermati Peluang dan Problematikanya, Jakarta: STID Mohammad Natsir Press, 2007,

Taimiyah, bin Ahmad, Majmu' Fatâwa, kitab At-Tafsir min Surah Al-A'raaf ila Surah Az-Zumar, Baerut: Ar-Risalah,1997 
Tim Penyusun Kamus Pembinaan dan Pengembangan Bahasa, Kamus Besar Bahasa Indonesia, Jakarta: Balai Pustaka, 1999

\section{Sumber dari Internet:}

http://www.alislamu.com,/tanggal 12 januari 2011

http://id.wikipedia.org/wiki/kampung tanggal 29/11/2010

http://id.wikipedia.org/wiki/Sawah tanggal 29/11/2010

\section{Wawancara:}

Diarto, Penanggung Jawab Multimedia, Wawancara, Bekasi, Ahad 27 Desember 2010

Muyasir, Sekertaris Yayasan Al Islam, Wawancara, Bekasi, Ahad 27 Desamber 2010

Imron Rosyadi, Mahasiswa Pesantren Tinggi Al Islam, Wawancara, Bekasi, Jum'at 11 Maret 2011

Pak Lurah Jati Melati, wawancara, Bekasi, kamis 10 Maret 2011

Sulaiman, Pak Rw 03, Wawancara, Bekasi, Kamis, 10 Maret 2011

Zein An Najah, Direktur Pesantren Tinggi Al Islam, Wawancara, Bekasi, Kamis, 10 Maret 2011 
Roni Namon, Ketua Rt 02, Wawancara, Bekasi, 16 April 2011

Jaza'ul Ihsan, imam dan pengurus mushalla sekaligus Ustadz di Kampung Rt 02 Rw 03 Kelurahan Jati Melati, Wawancara, Bekasi, Sabtu 16 April 2011

Farid Acmad Okbah, Ketua Yayasan Al Islam, Wawancara, Bekasi, Senin 18 April 2011

Ali, Ketua Karang Taruna, Wawancara, Bekasi, Juma’at 15 April 2011

Ahmad Kuding, Pengurus NU sekaligus DKM Masjid Al Hikmah, Wawancara, Bekasi, jum'at 15 April 2011

H. Abbas Imam Masjid Al Hikmah ketua IPM, kordinator PNPM mandiri, ketua NU ranting Jati Melati, Wawancara, Bekasi, Jum’at 15 April 2011

Zaenudin, Pengurus Masjid Ar Rahman, Wawancara, Bekasi, kamis 14 april 2011

\section{Sumber lain:}

Brosur Pesantren Tinggi Tahun 2009-2010

Akte Yayasan Al Islam, Tahun 2002 